\title{
Development of Hypertension in a Cohort of Cuban Adolescents
}

\author{
Marlene Ferrer MD PhD, José E. Fernández-Britto MD PhD DrSc, Jorge Bacallao PhD DrSc, Héctor Pérez MD MS
}

\begin{abstract}
INTRODUCTION Primary hypertension has its origins in childhood and is a risk factor for atherosclerosis; it is considered an important health problem because of its high prevalence worldwide.
\end{abstract}

OBJECTIVE Describe the development of hypertension during adolescence, including some factors that influence its persistence and progression in Cuban adolescents.

METHODS A cohort study was conducted in an intentional sample of 252 apparently healthy adolescents from the catchment area of the Héroes del Moncada Polyclinic in Plaza de la Revolución Municipality, Havana. They were assessed in two cross-sectional studies in 2004 and 2008. Mean age at first assessment was 13.2 years, 17.1 years at the second. Variables were weight, height, body mass index, waist circumference, blood pressure, smoking, family history of hypertension and birth weight. Correlation coefficients and growth curve analyses were applied to assess blood pressure persistence. Risk of developing prehypertension and hypertension was estimated in the second

\section{INTRODUCTION}

Atherosclerosis and related diseases are leading causes of death in countries where infections are not predominant.[1] Research focused on identifying atherogenic risk factors in children and adolescents shows that significant atherosclerosis precursors in adults are established early in life. This is when patterns of unhealthy diet, physical inactivity and smoking are formed, difficult to change later.[2,3]

Progression and severity of cardiovascular diseases are related to these risk factors and their persistence over time. Furthermore, longitudinal studies in pediatric populations show the tendency of cardiovascular risk factors to persist.[4] Such studies enable identification of persons at risk for cardiovascular diseases based on measurements made early in life. These risk factors may be useful as early screening targets, while care should be taken to correct abnormal values.[5]

Predisposition to atherosclerosis may already exist in childhood, induced by biological factors-both hereditary and nonhereditary-and environmental factors. All of the following in childhood are associated with coronary artery calcification and early cardiovascular disease: obesity, physical inactivity, hypertension (HT), high serum cholesterol, smoking and diabetes.[6]

Study of early signs of atherogenesis has been one of the main objectives of the Havana Atherosclerosis Research and Reference Center (CIRAH) since its creation. Between 1986 and 1996, WHO conducted a multinational research project entitled Pathobiological Determinants of Atherosclerosis in Youth,[6] and Cuba was one of 18 countries involved. Participation in this project led to a number of epidemiological studies demonstrating signs of early atherogenesis (most frequently overweight and HT) in children and adolescents. [7,8]

Hypertension is a major cardiovascular risk factor and is increasing worldwide, provoking extremely important health, assessment, based on predictors identified in the 2004 cut. Forecasting models with these factors were developed using classification trees as analytical tools.

RESULTS Of the six adolescents categorized as hypertensive in the first assessment, five still showed blood pressure alterations after four years. The main factors related to hypertension in those aged 16-19 were blood pressure itself and a body mass index $>90$ th percentile, followed by low birth weight and abdominal obesity. Prognostic models for predicting this condition at the end of adolescence demonstrated the importance of blood pressure alterations at age 12-15 years.

CONCLUSIONS High rates of persistence and progression of hypertension during adolescence highlights the need for systematic blood pressure screening at the primary health care level and adoption of primary prevention strategies beginning in childhood.

KEYWORDS Atherosclerosis, atherogenesis, high blood pressure, adolescence, hypertension, risk factors, Cuba social and economic problems. Reported prevalence in Cuban adults is about 30\%.[9] Global prevalence in children is not known precisely.[10,11] However, several studies have reported a high frequency of HT and pre-HT in Cuban children and adolescents. Fernández-Britto found $4.7 \%$ primary $\mathrm{HT}$ and $9.7 \%$ pre-HT in a sample of 1026 secondary school (grades 7 to 9) students of both sexes in Havana.[12] Álvarez reported similar findings in Havana,[13] while Suárez identified $9.3 \%$ of adolescents as hypertensive in Santiago de Cuba Municipality.[14] Despite these findings, the subject remains to be fully addressed in pediatrics.

Longitudinal studies in children and adolescents demonstrate that high blood pressure persists over time and can predict adult $\mathrm{HT}$.[4,5] Clinical perspectives on blood pressure in children have changed in recent years as a result of improved knowledge of normal values and systematic blood pressure measurement in well child visits. Thus, the importance of including regular blood pressure measurement in clinical practice is now widely recognized, both for early detection of asymptomatic HT in children and adolescents, and because HT early in life constitutes a risk marker for this condition in adulthood.[14] In 2009, the European Society of Hypertension declared HT in children a major and growing health problem requiring organized strategies to address it.[15]

Despite evidence showing the relationship between childhood and adult HT, research conclusions are inconsistent. Explanations of these inconsistencies include differences in cutoff points used, age groups selected, different followup times, and different methods for tracking blood pressure.[16]

Longitudinal studies describing evolution of atherogenic risk factors in children and adolescents are rare in Cuba. The purpose of our research was to describe blood pressure evolution and factors influencing HT persistence and progression in a cohort of Havana adolescents. Study outcomes will expand 
our knowledge on the subject and provide essential inputs for designing effective interventions at the primary health care level.

\section{METHODS}

A longitudinal study was conducted with two cross-sectional cuts, the first in 2004 and the second in 2008. The universe comprised 323 adolescents aged 12-15 years from the catchment area of Héroes del Moncada Polyclinic in Plaza de la Revolución Municipality, Havana, assessed in January-December 2004. Of these, 252 completed the second assessment in December 2008, constituting the study population ( $22 \%$ loss to followup).

Exclusion criteria Residence outside the polyclinic catchment area or absence at the time of the study; obesity or secondary $\mathrm{HT}$; pregnancy or recent childbirth.

Variables These are described in Table 1.

Table 1: Variables

\begin{tabular}{l|l}
\hline Variable & Description \\
\hline Age & Continuous variable (years) \\
Sex & Male, female \\
Weight & Continuous variable $(\mathrm{kg})$ \\
Height & Continuous variable $(\mathrm{cm})$ \\
\hline Waist circumference & Continuous variable $(\mathrm{cm})$
\end{tabular}

Ranked by BMI percentile [weight in $\mathrm{kg} /$ (height in $\mathrm{m})^{2}$ ] for Cuban children and adolescents[17] Malnourished: $<3$

Nutritional status Thin: $\geq 3$ and $<10$

Normal weight: $\geq 10$ and $<90$

Overweight: $\geq 90$ and $<97$

Obese: $\geq 97$

Abdominal obesity
SBP
DBP

Waist circumference, continuous variable $(\mathrm{cm})$ Ranked by percentile according to CDC[18] Normal: $\leq 90$ percentile Abdominal obesity: $>90$ percentile Continuous variable $(\mathrm{mmHg})$ Continuous variable $(\mathrm{mmHg})$

$\leq 18$ years of age: as per Fourth Report on Diagnosis, Evaluation and Treatment of High Blood Pressure in Children and Adolescents[19]

- Normal: SBP and DBP $<90$ percentile

- Pre-hypertension: SBP and/or DBP 90-95 percentile or values $\geq 120 / 80 \mathrm{mmHg}$

Blood pressure Hypertension: $>95$ percentile on $\geq 3$ occasions

$>18$ years of age: according to the Seventh

Report of the Joint National Committee on High

Blood Pressure [in adults][20]

- Normal: SBP and DBP $<120 / 80 \mathrm{mmHg}$

- Pre-hypertension: SBP 120-139 and/or DBP $80-89 \mathrm{mmHg}$

- Hypertension: $\geq 140 / 90 \mathrm{mmHg}$

$\begin{array}{ll}\text { Low birth weight } & \text { Yes (<2500 grams) } \\ \text { No ( } \geq 2500 \text { grams) }\end{array}$

No

- Nonsmoker: has never smoked cigarettes or any other tobacco product

- Passive smoker: passively exposed to tobacco smoke at home

Smoking

- Active smoker: reported having smoked one day or more within 30 days prior to assessment

BMI: body mass index DBP: diastolic blood pressure HT: hypertension SBP: systolic blood pressure
Procedures Before the study began, researchers visited each site-the family-doctor-and-nurse office corresponding to each participant-to ensure that measurement conditions were satisfactory. In addition, one of the authors was present at each session to monitor compliance with accuracy standards. Each child was interviewed and examined in the presence of his/her family in order to avoid omission bias regarding family history and birth weight. Data were collected using CIRAH's primary data collection form.

Anthropometric measurements including weight, height and waist circumference were performed in both assessments. For body mass index, the Quetelet index [weight in $\mathrm{kg} /(\text { height in } \mathrm{m})^{2}$ ] was used. Equipment was calibrated and monitored in accordance with International Biological Program standards.[21] Research team members at each site received training on study procedures, and measurements were taken by the same research team on both study dates.

Initial anthropometric measurements taken at each assessment were replicated twice, for a total of three measurements on the same day, and the average was calculated. As a data quality control procedure, five adolescents were randomly selected and all measurements were repeated. This process included calculation of technical measurement error and reliability index.

Systolic and diastolic blood pressure were taken after subjects had rested for five minutes, each sitting upright with the right arm positioned at heart level,[19] and without having smoked or taken medication that day. An aneroid blood pressure cuff and calibrated stethoscope (SMIC, China) were used. Repeated measurements were taken at five-minute intervals.

Statistical analysis Data were processed with SPSS for Windows, version 18.0. Persistence was analyzed by building dual-entry tables to relate blood pressure classification on initial assessment with that of final assessment. Odds ratios and $95 \%$ confidence intervals were calculated for blood pressure alteration at age 16-19 years. Classification trees were used as prognostic models for pre-HT and HT at final assessment, based on factors identified initially. The classification trees allowed us to identify which independent variables were most important as predictors of blood pressure alterations at age 16-19 years. They are also a practical, easily interpreted method for determining HT persistence and establishing optimal cutoff points for the sample. The chi-square automatic interaction detection method was used.[22] The classification trees were constructed with ordinal variables, and also with continuous variables in order to find optimal cutoff points according to their original measurements. Two variants were used for continuous variables: as continuous variables and as categorical synthetic variables. In practice, the latter may be a preferred option because it provides simpler prediction algorithms, while the former is more informative analytically, since it further proposes optimal cutoff points and allows for inclusion of possible nonlinear relationships among predictors and risk, thereby producing more sensitive forecasts.

Ethical considerations The study was reviewed and approved by the CIRAH ethics committee. Written informed consent was obtained from the participants and their parents or guardians.

\section{RESULTS}

Mean participant age was 13.2 years at the first assessment, and 17.1 years at the second. Sex composition was balanced. 
HT was detected in six teenagers in the initial assessment, of whom only one moved to a lower percentile after four years. Of the 18 prehypertensive teens, 8 (44.4\%) persisted as such, and 3 (16.7\%) progressed to HT (Table 2). The OR for HT in the second measurement was 4.9 for adolescents with blood pressure $>90$ th percentile at age 12-15 years. Next, in order of importance, came BMI >90th percentile (OR 3.6), low birth weight, and waist circumference $>90$ th percentile (Figure 1 ).

Table 2: Relationship between initial and final BP classifications

\begin{tabular}{|c|c|c|c|c|c|c|c|}
\hline \multicolumn{8}{|l|}{ Final BP } \\
\hline \multirow[t]{2}{*}{ Initial BP } & \multicolumn{2}{|c|}{ Normal } & \multicolumn{2}{|c|}{ Pre-HT } & \multicolumn{2}{|c|}{$\mathrm{HT}$} & \multirow{2}{*}{$\frac{\begin{array}{c}\text { Initial } \\
\text { total }\end{array}}{n}$} \\
\hline & $n$ & $\%$ & $n$ & $\%$ & 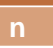 & $\%$ & \\
\hline Normal & 197 & 86.4 & 27 & 11.8 & 4 & 1.8 & 228 \\
\hline Pre-HT & 7 & 38.9 & 8 & 44.4 & 3 & 16.7 & 18 \\
\hline HT & 1 & 16.7 & 3 & 50.0 & 2 & 33.3 & 6 \\
\hline Final total $\downarrow$ & 205 & 81.3 & 38 & 15.1 & 9 & 3.6 & 252 \\
\hline
\end{tabular}

BP: blood pressure HT: hypertension Pre-HT: pre-hypertension

Figure 1: Risk of abnormal BP at age 16-19 according to predictors at age $12-15$ years

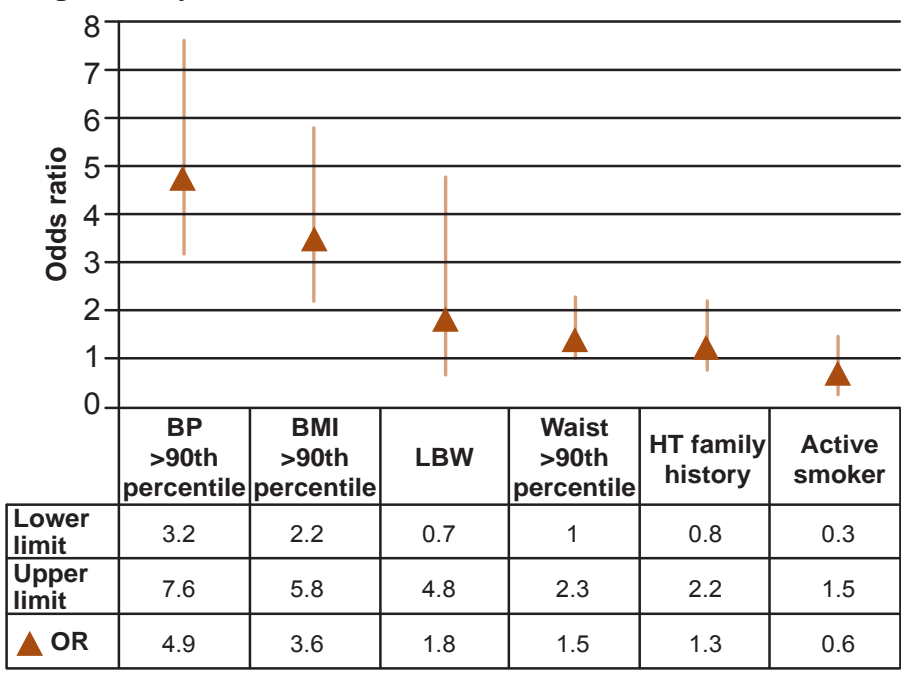

Predictors at age $12-15$ years

BMI: body mass index BP: blood pressure $\mathrm{Cl}$ : confidence interval HT: hypertension LBW: low birth weight

At each step, the chi-square automatic interaction detection classification tree effected different partitions, choosing from among all independent variables entered into the model the one showing the strongest interaction with the dependent variable. Blood pressure classification in the initial assessment at the beginning of the study, nutritional assessment classification, waist circumference, and family history of HT and smoking were introduced into the model. Blood pressure classification at the beginning of the study was selected by the model as the most important variable for predicting being prehypertensive or hypertensive at the second assessment. Figure 2 shows the classification tree with blood pressure as a categorical variable. Teens who initially had altered blood pressure had a $66.7 \%$ risk of being hypertensive or prehypertensive by age 16-19.

By introducing as predictors the independent variables SBP, $\mathrm{DBP}$, waist circumference and BMI treated as continuous, the model made two partitions, selecting first SBP and then BMI.
Figure 2: Prediction of BP at age 16-19 years by BP at age 12-15 years (CHAID classification tree, categorical variable)

Classification of BP2 Category

\begin{tabular}{|lrr|}
\hline \multicolumn{3}{|c|}{ Node 0} \\
Category & $\%$ & \multicolumn{1}{c|}{$\mathrm{n}$} \\
\hline $\begin{array}{l}\text { normal } \\
\text { prehypertensive } \\
\text { or hypertensive }\end{array}$ & 18.7 & 205 \\
\hline Total & 100.0 & 252 \\
\hline
\end{tabular}

Classification of BP1 Category Improvement $=0.049$

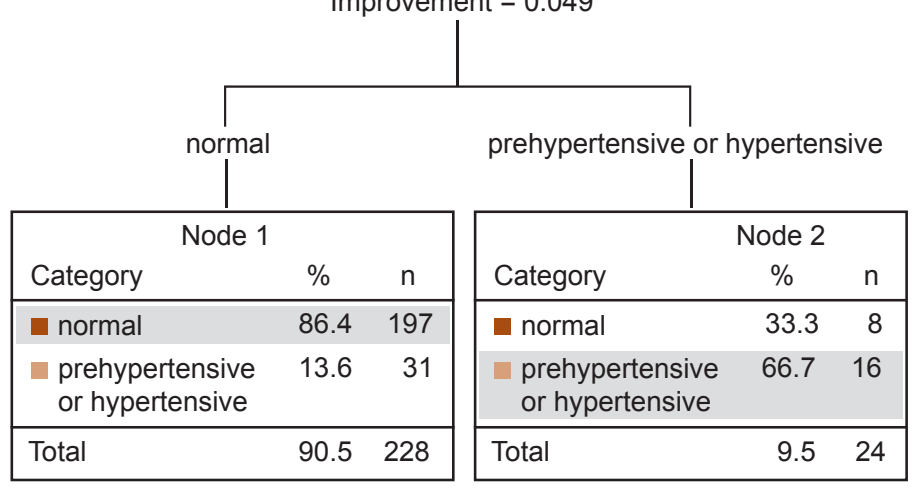

BP1: blood pressure at age 12-15 years BP2: blood pressure at age 16-19 years CHAID: chi-square automatic interaction detection

When SBP at age 12-15 years was $>110 \mathrm{mmHg}$, risk of becoming prehypertensive or hypertensive was about $50 \%$. If SBP was between $98-110 \mathrm{mmHg}$, with a BMI $>20.4$, risk was almost $30 \%$ (Figure 3).

When stratified by sex, different effects of continuous variables were observed for male and female subjects. The most important variable for male subjects was SBP, followed by BMI. When SBP values at age $12-15$ were $>110 \mathrm{mmHg}$, the probability of becoming hypertensive or prehypertensive in 4 years' time was $68 \%$. For female subjects, however, the tree structure changed completely, especially in the terminal nodes, showing waist circumference as the main variable, followed by DBP, with a risk of $24 \%$ if waist circumference was $>68 \mathrm{~cm}$, increasing to $36.7 \%$ if DBP $>60 \mathrm{mmHg}$ was also present at the beginning of the study (Figure 4).

\section{DISCUSSION}

Adolescence is a complex stage of human development because the growth that has occurred continuously from conception is combined with signs of maturity apparent with the onset of puberty. During this stage, behavioral patterns are established and some risk factors come to light that influence health at the beginning of adulthood.

Blood pressure values in childhood tend to remain on the same growth curve over time, which means that children in higher blood pressure percentiles will remain in that range into adulthood. This tracking pattern starts early on, which supports the hypothesis that primary HT begins in childhood.[23]

Although information regarding progression from pre-HT to HT among adolescents is limited, the persistence of HT observed in this study is in line with research suggesting that children and 
Figure 3: Prediction of BP at age 16-19 years by BP at age 12-15 years (CHAID classification tree, continuous variable)

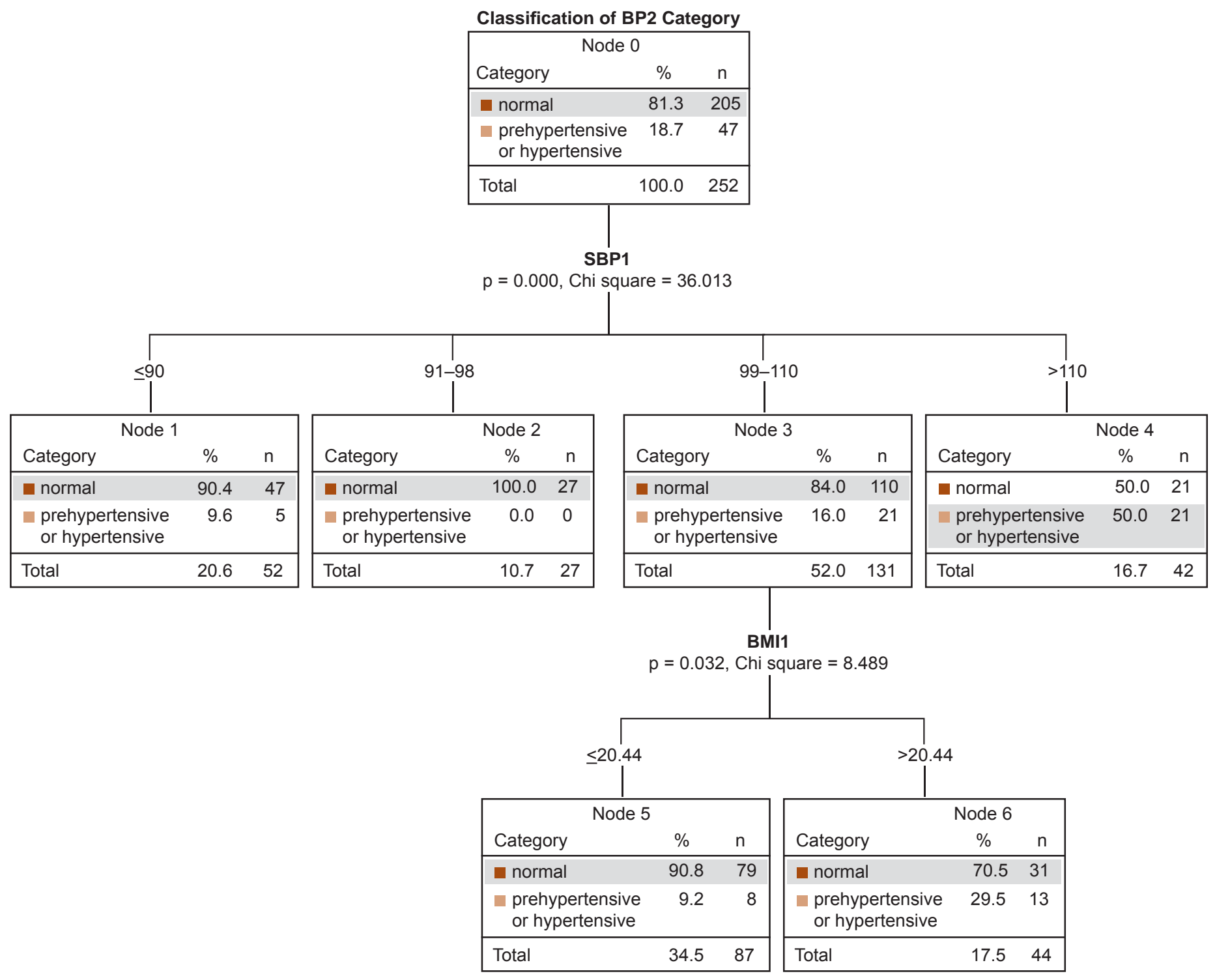

BMI1: body mass index at age 12-15 BP2: blood pressure at age 16-19
SBP1: systolic blood pressure at age 12-15 years CHAID: chi-square automatic interaction detection adolescents with blood pressure at the high end of the distribution tend to have HT as young adults. $[5,16,23]$

Data from a US study to determine the consequences of HT in adolescence suggest that progression from pre-HT to HT (based on a single measurement) is approximately $7 \%$ per year, and that pre-HT carries a high risk of progression to $\mathrm{HT}$ in adolescence. [10] It is estimated that individuals with DBP near $90 \mathrm{mmHg}$ when aged 15 years are twice as likely to have DBP $>90 \mathrm{mmHg}$ at age 35 years as those with lower initial values.[24-26]

Field reported a risk of developing altered blood pressure 5.1 times higher in children with $\mathrm{BMI}>85$ th percentile.[27] The classification trees in our study confirmed the persistence of HT through adolescence. Furthermore, results showed that BMI at age 12-15 years is associated with alterations in blood pressure later in adolescence. This relationship could be explained by three main pathophysiological mechanisms: impaired autonomic function, insulin resistance, and abnormalities in vascular structure and function. This link may be mediated by the sympathetic nervous system, with a hyperactive state that has been confirmed in different studies involving obese children and adolescents.[28]

Lower vascular compliance has been found in obese children, similar to that of children with diabetes and familial hypercholesterolemia. Endothelial dysfunction has also been suggested as a problem associated with obesity. Recent research links obesity, C-reactive protein and SBP, suggesting a possible pathophysiological mechanism: impaired vascular function caused by chronic inflammation in obese children as a predictor for developing HT.[29,30]

A cohort study of Brazilian children who were followed for 17 years to adulthood showed that sustained elevated blood pressure was associated with a more unfavorable cardiovascular risk profile, 
Figure 4: Prediction of BP at age 16-19 years by BP at age 12-15 years (classification trees, continuous variables), by sex

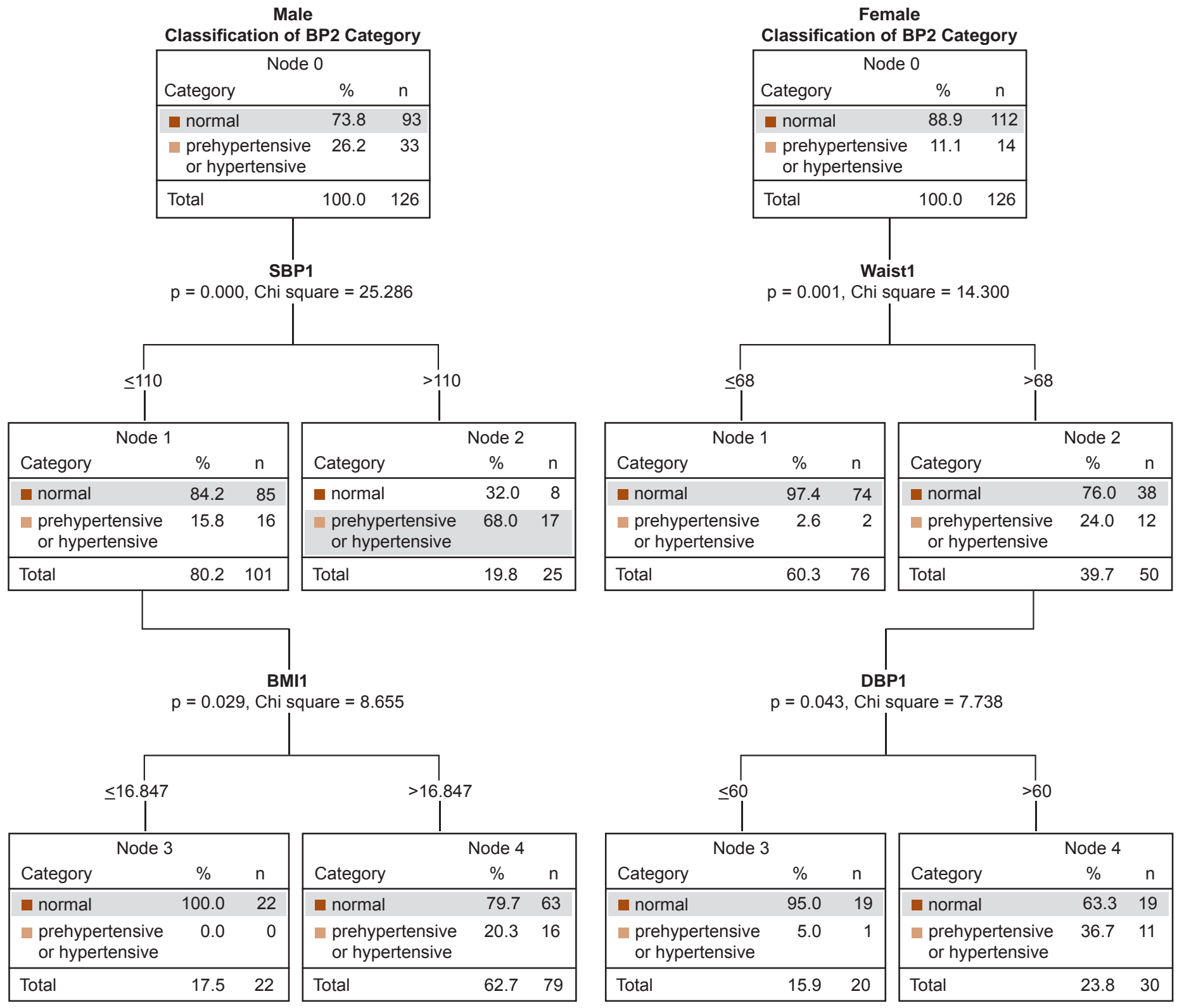

BMI1: body mass index at age 12-15 years BP2: blood pressure at age 16-19 years Waist1: waist circumference at age $12-15$ years
SBP1: systolic blood pressure at age $12-15$ years DBP1: diastolic blood pressure at age 12-15 years with higher prevalence of $\mathrm{HT}$, overweight/obesity, lipid and glucose abnormalities, and metabolic syndrome in adulthood,[31] confirming the need for preventive measures beginning early in life.

Sex differences found in the classification trees highlight the behavior of this variable as an effect modifier. It should be borne in mind that in the first stage of the research, children were between early and middle adolescence, which coincides with a period of rapid growth. Increases in blood pressure with age are related to body size and can differ by sex, since puberty occurs at different ages for boys and girls. Puberty is a time of important anthropometric, hormonal and lipid changes associated with sexual maturation, which contribute to differences in cardiovascular risk factors between the sexes.[23,32,33]
Evidence suggests that elevated blood pressure in childhood is a predictor for $\mathrm{HT}$ in adulthood and that some lifestyle-related risk factors, such as unhealthy diet and physical inactivity, remain stable from childhood on; hence prevention is more effective if lifestyles are changed early in life.[33]

While some research conducted in Cuba shows early atherogenic signs in children and adolescents, few studies aim at understanding its progression.[1,7,8,12-14] Pérez addressed the question of progression to HT in a longitudinal study involving prehypertensive children in the city of Santa Clara. He concluded that the interaction from adolescence to adulthood of such factors as age at onset of pre-HT, birth weight, family obesity and an unfavor- 
able family environment contributed to progression from pre-HT to HT.[34]

This study describes the progression of HT in a cohort of adolescents. Within its scope, it was possible to identify early signs of atherogenesis in a group of adolescents who appeared healthy when first examined. This research demonstrates the need for appropriate blood pressure screening and management in order to avoid adverse health outcomes later in life.

\section{CONCLUSIONS}

The high persistence and the progression of HT in adolescence highlight the need for systematic screening at the primary health care level as well as adoption of primary prevention strategies from an early age. -1 -

\section{REFERENCES}

1. Fernández-Britto JE, Wong R, Contreras D, Nordet P, Nils D. Aterosclerosis en la juventud I. Patomorfología y morfometría utilizando el Sistema Aterométrico. Rev Cubana Invest Biomed. 1998 May-Aug;17(2):128-42. Spanish.

2. Berenson GS. Cardiovascular risk begins in child: A time for action. Am J Prev Med. 2009 Jul;37(1 Suppl):S1-2.

3. Duhagon P, Falero P, Farré Y, Gambeta JC, Gutierrez G, Köncke F, et al. Promoción de la salud cardiovascular en la infancia. Arch Pediatr Urug. 2005 May;76(1):51-8. Spanish.

4. Foulkes MA, Davis CE. An index of tracking for longitudinal data. Biometrics. 1981;37:439-46.

5. Lauer RM, Anderson AR, Beaglehole R, Burns TL. Factors related to tracking of blood pressure in children. U.S. National Center for Health Statistics Health Examination Surveys Cycles II and III. Hypertension. 1984 MayJun;6(3):307-14.

6. Mendis S, Nordet P, Fernandez-Britto JE, Sternby N. Atherosclerosis in children and young adults: An overview of the World Health Organization and International Society and Federation of Cardiology study on Pathobiological Determinants of Atherosclerosis in Youth study (1985-1995). Global Heart. 2005 Mar;1(1):3-15.

7. Ferrer Arrocha M, Núñez García M, Gómez Nario O, Miguélez Nodarse R, Pérez Assef $\mathrm{H}$. Factores de riesgo aterogénico en adolescentes de secundaria básica. Rev Cubana Pediatr [Internet]. 2008 Jun [cited 2013 Sep 26];80(2). Available from: http://bvs.sld.cu/revistas/ped/ vol80_2_08/ped02208.htm. Spanish.

8. Ferrer Arrocha $M$, Rodríguez Fernández $C$, González Pedroso MT, Díaz Dehesa MB, Núñez García MV. Obesidad, hipertensión y tabaquismo: señales ateroscleróticas tempranas en adolescentes de la secundaria básica "Guido Fuentes". Rev Cubana Invest Biomed [Internet]. 2009 Mar [cited 2013 Sep 26];28(2). Available from: http://scielo.sld .cu/scielo.php?script=sci_arttext\&pid=S0864 $-03002009000200006 \&$ Ing=es. Spanish

9. Castillo Herrera JA, Villafranca Hernández O. La hipertensión arterial primaria en edades tempranas de la vida, un reto a los servicios de salud. Rev Cubana Invest Biomed [Internet]. 2009 Jul-Sep [cited 2013 Sep 26];28(3):14757. Available from: http://scielo.sld.cu/ scielo.php?script=sci_arttext\&pid=S0864 $-03002009000300012 \&$ Ing=es. Spanish.

10. McNiece KL, Poffenbarger TS, Turner JL, Franco KD, Sorof JM, Portman RJ. Prevalence of hypertension and prehypertension among adolescents. J Pediatr. 2007 Jun;150(6):640-4.

11. Folkner B, Gidding SS. Prehipertensión en los adolescentes. Hipertensión (Madr.). 2008;25(6):245-8. Spanish.

12. Fernández-Britto Rodríguez JE, Barriuso Andino A, Chiang MT, Pereira A, Toros Xavier $\mathrm{H}$, Castillo Herrera JA, et al. La señal aterogénica temprana: estudio multinacional de 4934 niños y jóvenes y 1278 autopsias. Rev Cubana Invest Biomed [Internet]. 2005 Sep [cited 2012
Feb 15];24(3). Available from: http://scielo.sld .cu/scielo.php?script=sci_arttext\&pid=S0864 $-03002005000300002 \&$ Ing=es. Spanish.

13. Álvarez Gómez JL, Terrero Eumelia O, Díaz Novás J, Ferrer Arrocha M. Exceso de peso corporal e hipertensión arterial en adolescentes de secundaria básica. Rev Cubana Med Gen Integr [Internet]. 2010 Mar [cited 2010 Oct 13];26(1):[about 5 p.]. Available from: http:// www.bvs.sld.cu/revistas/mgi/vol_26_1_10/ mgi04110.htm. Spanish.

14. Suárez Cobas L, Rodríguez Constantín A, Tamayo Velásquez JL, Rodríguez Beyrís RP. Prevalencia de hipertensión arterial en adolescentes de 15 a 17 años. MEDISAN [Internet]. 2009 [cited 2010 Mar 3];13(6):[about 6 p.]. Available from: http://bvs.sld.cu/revistas/san/ vol13_6_09/san07609.htm. Spanish.

15. Lurbe E, Cifkova R, Cruickshank K, Dillon MJ, Ferreira I, Invitti C, et al. Management of high blood pressure in children and adolescents: recommendations of the European Society of Hypertension. J Hypertens. 2009 Sep;27(9):1719-42.

16. Chen $X$, Wang $Y$. Tracking of blood pressure from childhood to adulthood: A systematic review and meta-regression analysis. Circulation. 2008 Jun 24;117(25):3171-80.

17. Gutierrez JA, Berdasco A, Esquivel M, Jiménez JM, Posada E, Romero JM, et al. Crecimiento y desarrollo. In: De la Torre E, Pelayo E, editors. Pediatría. Tomo I. Havana: Editorial Ciencias Médicas; 2006. p. 27-58. Spanish.

18. Mc Dowell MA, Fryar CD, Hirsch R, Ogden CL, Ogden S. Anthropometric Reference Data for Children and Adults: U. S Population, 19992002. Adv Data [Internet]. 2005 Jul 7 [cited 2013 Sep 26];(361):1-5. Available from: http:// www.cdc.gov/nchs/data/ad/ad361.pdf

19. National High Blood Pressure Education Program Working Group on High Blood Pressure in Children and Adolescents. The Fourth Report on Diagnosis, Evaluation and Treatment of High Blood Pressure in Children and Adolescent. Pediatrics. 2004 Aug;114(2 Suppl 4th Report):555-76.

20. Verdecchia P, Angeli F. Séptimo informe del Joint National Commitee para la prevención, detección evaluación y tratamiento de la hipertensión arterial: el armamento está a punto. Rev Esp Cardiol. 2003 Sep;56(9):8437. Spanish.

21. Weiner JS, Lourie JA. Human Biology: A guide to field methods. Oxford: Blackwell Scientific Publications; 1969.

22. Richard's MM, Solanas A, Ledesma RD, Introzzi IM, López Ramón MF. Técnicas estadísticas de clasificación: un estudio comparativo y aplicado. Psicothema. 2008 Nov;20(4):863-71. Spanish.

23. Paul TK, Chen W, Srinivasan SR, Rice J, Toprak A, He J, et al. Framingham risk score is associated with femoral artery intima-media thickness in asymptomatic young adults (the Bogalusa Heart Study). Atherosclerosis. 2010 Dec;213(2):627-31.
24. Juonala M, Magnussen CG, Venn A, Dwayer $\mathrm{T}$, Burns $\mathrm{TL}$, Davis $\mathrm{PH}$, et al. Influence of age on associations between childhood risk factors and carotid Intima-Media thickness in adulthood: the Cardiovascular Risk in Young Finns Study, the Childhood Determinants of Adult Health Study, the Bogalusa Heart Study, and the Muscatine Study for the International Childhood Cardiovascular Cohort (i3C) Consortium. Circulation. 2010 Dec 14;122(24):2514-20.

25. Bao W, Threefoot SA, Srinivasan SR, Berenson GR. Essential hypertension predicted by tracking of elevated blood pressure from childhood to adulthood: the Bogalusa Heart Study. Am J Hypertens. 1995 Jul;8(7):657-65.

26. Laclaustra-Gimeno M, González-García MP, Casasnovas-Lenguas JA, Luengo-Fernández $E$, León-Latre $M$, Portero-Pérez $P$, et al. Cardiovascular risk factor progression in young males at 15-year follow-up in the General Military Academy of Zaragoza (AGEMZA) Study. Rev Esp Cardiol. 2006 Jul;59(7):671-8.

27. Field AE, Cook NR, Gillman MW. Weight status in childhood as a predictor of becoming overweight or hypertensive in early adulthood. Obes Res. 2005 Jan;13(1):163-9.

28. Sorof JM, Franko K, Bernard L, Portman RJ Isolated systolic hypertension, obesity and hyperkinetic hemodynamic states in children. $J$ Pediatr. 2002 Jun;140(6):660-6.

29. López-Jaramillo P, Herrera E, García RG, Camacho PA, Castillo VR. Inter-relationships between Body Mass Index, C-reactive protein and blood pressure in a Hispanic pediatric population. Am J Hypertens. 2008 May;21(5):527-32.

30. Toprak D, Toprak A, Chen W, Xu JH, Srinivasan R, Berenson GS. Adiposity in childhood is related to C-Reactive Protein and adiponectin in young adulthood: from the Bogalusa Heart Study. Obesity (Silver Spring). 2011 Jan;19(1):185-90.

31. Conçalves Campana ME, Araujo Brandao A Pozzan R, Fraça MF, Lopes Fonseca F, Pizzi $\mathrm{OL}$, et al. Presión arterial en jóvenes como marcador de riesgo cardiovascular en jóvenes estudio de Rio de Janeiro. Arq Bras Cardiol. 2009 Dec;93(6):639-47. Spanish, English, Portuguese.

32. Juárez-Rojas JG, Cardoso-Saldaña GC Posadas-Sánchez R, Medina-Urrutia AX, Yamamoto-Kimura L, Posadas-Romero C. Blood pressure and associated cardiovascular risk factors in adolescents of Mexico City. Arch Cardiol Mexico. 2008 Oct-Dec;78(4):834-91.

33. Lazarou C, Panagiotakos DB, Matalas AL. Lifestyle factors are determinants of children's blood pressure levels: the CYKIDS study. J Hum Hypertens. 2009 Jul;23(7):456-63.

34. Pérez Fernández GA, Grau Abalo R. Predicción de la evolución hacia la hipertensión arterial en la adultez desde la adolescencia. Rev Cubana Inform Med [Internet]. 2012 [cited 2013 Sep 26];12(1):[about 30 p.]. Available from: http://www.rcim.sld.cu/revista_24/articu lo_pdf/hipertensionarterial.pdf. Spanish. 


\section{THE AUTHORS}

Marlene Ferrer Arrocha (Corresponding author: marlene.ferrer@infomed.sld.cu), pediatrician with a doctorate in medical sciences. Full professor and adjunct researcher, Havana Atherosclerosis Research and Reference Center (CIRAH), Cuba.

José Emilio Fernández-Britto Rodríguez, anatomical pathologist. Emeritus professor and researcher, and current director, CIRAH, Cuba.

Jorge Bacallao Gallestey, mathematician and biostatistician. Full professor, CIRAH, Cuba.

Héctor Pérez Assef, cardiologist and intensivist. Associate professor, Hermanos Ameijeiras
Clinical-Surgical Teaching Hospital, Havana, Cuba.

Submitted: June 5, 2013

Approved for publication: December 23, 2014 Disclosures: None

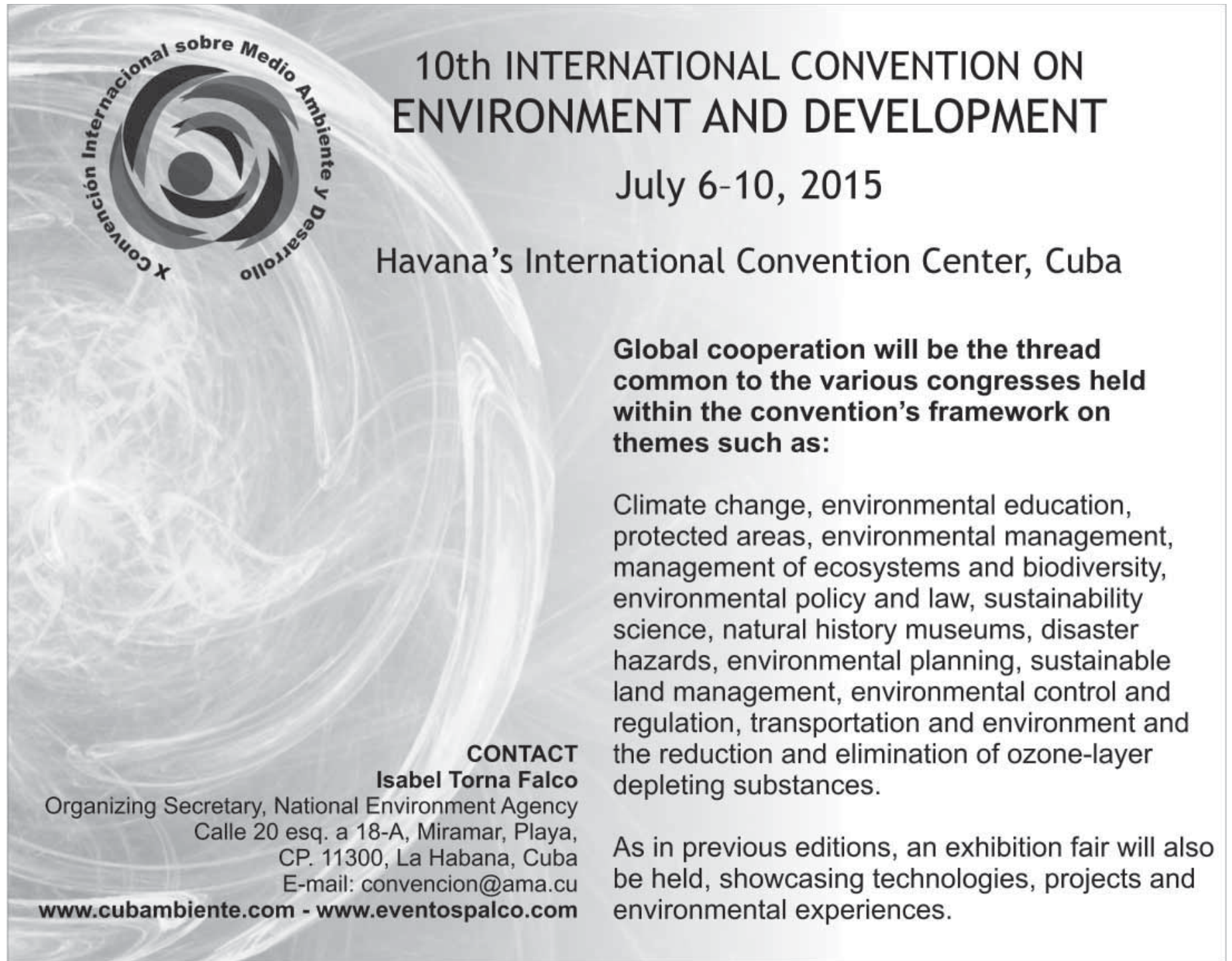

